\title{
University Students' Perceptions of the Reasons for Success and Failure: A Qualitative Study
}

\author{
Ferdi Bahadır (Corresponding author) \\ Department of Educational Sciences, Erzincan Binali Yıldırım University, Turkey \\ Tel: 90-446-224-0089-42160Ｅ-mail: ferdibahadir@hotmail.com
}

Received: August 19, 2020

Accepted: September 26, 2020 Published: October 11, 2020

doi:10.5296/jei.v6i2.17560

URL: https://doi.org/10.5296/jei.v6i2.17560

\begin{abstract}
This study aims to reveal the reasons for students' success and failure based on their own perceptions. University students served as the participants of this study in which the phenomenological method was used. Data was collected with the listing questions, developed by the researcher, which took place in the semi-structured interview form. According to the results of the study, the factors that affect both success and failure the most are personal. In addition, findings suggest that success is a relative concept from one's personal perspective. It is thought that monitoring students and organizing both learning and sheltering environments, in accordance with their interests and needs after they are placed in university, will boost their success. Further studies may provide different perspectives by focusing on the reasons for success and failure based on the opinions of families and academics.
\end{abstract}

Keywords: reasons for success, reasons for failure, qualitative research, success and failure, teacher training

\section{Introduction}

In every aspect of life, people have certain responsibilities, and whether these responsibilities are fulfilled properly is represented with certain words, which are considered criteria. Two of those criteria are antonymous words, success and failure. These two words are used as indicators of whether students achieve their goals in their educational lives, as well as being used at every moment of life. While Yaşar and Balkıs (2004) define success as students' improvement in achieving designated results with regard to cognitive behaviors, including knowledge and aptitude, they state that apart from these, academic success also encapsulates non-cognitive behaviors, such as personal traits and attitudes. Academic failure can be defined as the difference between students' expected and observed performance (Soydaş \& Bayraker, 2006). From another angle, failure can also be defined as the individual underachieves considerably compared to students who show school success on an average 
(Topbaş, 1998). Failure is a field of study on which researchers have been putting emphasis for years. As a result, a significant amount of research about student failure has been presented in the literature (Bean, Bush, McKenry, \& Wilson, 2003; Boozer \& Rouse, 2001; Erdil, 2010; Kandemir, 2012; Maton, Hrabowski, \& Greif, 1998; Patır \& Y1ldı, 2008). However, with the changing world and human race, different reasons for failure have been increasingly emerging problematic.

Education is teamwork (Akbaba-Altun \& Cakan, 2008). Failure can result from different factors and the student themself. When looking at the reasons that researchers attribute to failure, Purdue and Hattie (1999) consider students' decision on appropriate study strategies as significant, whereas Silah (1994) suggests that students' academic success can be affected by several physical, psychological, social factors. Tezcan (1999) lists the reasons for failure as the motives arising from innate genetic and personal features, family, school's quality, and economic opportunities. Aslanargun (2007) attributes students' failure to the communicative disorders that nonfunctional school-parent association brings. Şama and Tarım (2007) also point out that the most important reasons for failure are family apathy, peaceless family environment, education levels of family members and economic conditions of families. While Altınkurt (2008) attributes failure to absenteeism to school, Çalık (2011), Yaşar and Balkıs (2004), Özabacı and Acat (2005) emphasize that it changes according to ineffective class management, students' lack of efficient studying methods and their perceptions of instructors, the socio-economic environment where the school is located respectively.

Identifying the reasons for failure is significant in the sense that it provides stakeholders with data (Akbaba-Altun, 2009). When looking at previous research, that failure is usually associated with the reasons related to individual, family and the environment has been observed (Ar1c1, 2007a, 2007b; Klomegah, 2007; Özer \& An1l, 2011; Polat, 2009; Wang, 2004). The fact that scientific research must be conducted problem-based leads researcher to detect mostly the negative conditions. However, identifying the reasons for success as well as failure is believed to guide students. Just as identifying the reasons for failure is considered important to abstain from it, identifying the reasons for success is considered important to provide students with the environment for success. Further, when the subject is failure, elementary and middle school students is usually the first thing that spring to mind. Failure addressing the school subjects, particularly mathematics, is one of the prevalent research topics. As for the universities, it is likely to see that there are students who are in a muddle even though they have a successful educational background and are placed in the departments which accept students with a high score. Contrary to this, there may be students who increase their success. This study is noteworthy in terms of contributing to identifying university students' success and failure in their university education life.

From another perspective, even though success and failure are compared by means of quantitative measurement, individuals' own perceptions can also be regarded as a measure. That is, one of two individuals who has the same success average might describe himself as successful, the other one as unsuccessful. This study is also considered noteworthy in terms of identifying students' perceptions of success since whether students are successful is discussed according to their own perceptions. In other words, individuals were asked if they 


\section{Macrothink}

regard themselves as successful or not and in accordance with their answers, the reasons were analyzed. In this sense, the aim of this study is determined to identify university students' perceptions of the reasons for success and failure. With this purpose in mind, answers for the questions below were sought out.

- What are "personal" factors that affect success according to university students?

- What are "family" factors that affect success according to university students?

- What are "environmental" factors that affect success according to university students?

- What are "personal" factors that affect failure according to university students?

- What are "family" factors that affect failure according to university students?

- What are "environmental" factors that affect failure according to university students?

\section{Method}

\subsection{Research Design}

Since this study aims to reveal the students' experiences, the meaning of those experiences and the reasons for success and failure based on their own perceptions, phenomenological method was chosen as the research design. Phenomenology, a method of examining and identifying ontology of objects, seeks to answer the question of "what is real" (Baş \& Akturan, 2013; Creswell, 2007). Phenomenological studies focus on the phenomena that are noticed but do not have a profound and an elaborate insight (Mayring, 2000; Taylor and Bogdan, 1984).

\subsection{Participants}

The sample of this study consisted of 34 sophomore students of a department at a university. While determining participants, one of the purposive sampling methods, criterion-sampling technique, was used. The main principle of criterion sampling is to study all situations which correspond to a series of predetermined criteria (Yıldırım \& Şimşek, 2011). In this sense, the criterion in this study is that besides studying in the same department and the class, the students have taken the same lessons so far. Briefly, that their university education life is similar is determined as the criterion. Table 1 presents the features of the participants. 
Table 1. Some information about sample group

\begin{tabular}{|c|c|c|c|}
\hline & Participants & CGPA & Gender \\
\hline \multirow{18}{*}{$\begin{array}{l}\text { The participants who consider } \\
\text { themselves as "SUCCESSFUL" }\end{array}$} & Participant 1 & 2.13 & Female \\
\hline & Participant 2 & 2.22 & Female \\
\hline & Participant 3 & 2.50 & Female \\
\hline & Participant 4 & 2.57 & Female \\
\hline & Participant 5 & 2.82 & Female \\
\hline & Participant 6 & 2.86 & Female \\
\hline & Participant 7 & 2.87 & Female \\
\hline & Participant 8 & 2.92 & Female \\
\hline & Participant 9 & 3.02 & Female \\
\hline & Participant 10 & 3.03 & Male \\
\hline & Participant 11 & 3.08 & Female \\
\hline & Participant 12 & 3.15 & Female \\
\hline & Participant 13 & 3.15 & Female \\
\hline & Participant 14 & 3.25 & Male \\
\hline & Participant 15 & 3.43 & Male \\
\hline & Participant 16 & 3.50 & Female \\
\hline & Participant 17 & 3.62 & Female \\
\hline & Participant 18 & 3.69 & Female \\
\hline Average CGPA & - & 2.98 & - \\
\hline \multirow{16}{*}{$\begin{array}{l}\text { The participants who consider } \\
\text { themselves as "UNSUCCESSFUL" }\end{array}$} & Participant 19 & 2.16 & Female \\
\hline & Participant 20 & 2.18 & Female \\
\hline & Participant 21 & 2.22 & Male \\
\hline & Participant 22 & 2.33 & Male \\
\hline & Participant 23 & 2.37 & Female \\
\hline & Participant 24 & 2.38 & Female \\
\hline & Participant 25 & 2.41 & Female \\
\hline & Participant 26 & 2.47 & Female \\
\hline & Participant 27 & 2.51 & Female \\
\hline & Participant 28 & 2.53 & Female \\
\hline & Participant 29 & 2.60 & Female \\
\hline & Participant 30 & 2.63 & Female \\
\hline & Participant 31 & 2.66 & Female \\
\hline & Participant 32 & 2.78 & Male \\
\hline & Participant 33 & 2.91 & Female \\
\hline & Participant 34 & 3.11 & Female \\
\hline Average CGPA & - & 2.51 & - \\
\hline
\end{tabular}


As can be seen in Table 1, while 18 out of 34 participants $(52.9 \%)$ consider themselves as successful, 16 of them (47.1\%) as unsuccessful. Among the participants who consider themselves as successful, the score of the one who has the lowest CGPA is 2.13 whereas the score of the one who has the highest CGPA is 3.69. The average of these 18 students' CGPA is 2.98. Among the participants who consider themselves as unsuccessful, the score of the one who has the lowest CGPA is 2.16 while the score of the one who has the highest CGPA is 3.11. The average of these 16 students' CGPA is 2.51 . Three $(16.7 \%)$ of the participants who consider themselves as successful are male, $15(83.3 \%)$ are female. Three $(18.7 \%)$ of the participants who consider themselves as unsuccessful are male, $13(81.3 \%)$ are female. In total, six $(17.6 \%)$ of the participants are male, $28(82.4 \%)$ are female.

\subsection{Data Collection}

Data was collected with the listing questions, developed by the researcher, which took place in the semi-structured interview form. Listing questions are beneficial considering that they enable the answers of open-ended questions to be presented in an order (Büyüköztürk, Kılıç Çakmak, Akgün, Karadeniz, \& Demirel, 2012). After literature review, three questions regarding the factors (personal, family and environment) which affect success and three questions regarding the factors (personal, family and environment) which affect failure, six questions in total, were designated. Data collection tool was designated in the way that the participants were asked whether they consider themselves successful or not first, the ones who gave the answer 'Yes' were asked further questions related to the reasons for their success, the ones who gave the answer 'No' were asked further questions related to their failure. These questions were shared with four domain experts afterwards. According to the feedback given by the experts, the questions were revised in such a way that they can be more intelligible; thus, content validity is ensured. Then, this data collection tool was applied to three students in order to confirm that the questions were understood in the correct way; thus, reliability is ensured. Moreover, the researcher avoided expressing his own opinion, assured the participants about data not to be used for other purposes apart from this study and provided exact quotations of some participants' answers, which contributed to the reliability and validity of the study.

\subsection{Data Analysis}

One of the qualitative data analysis techniques, content analysis was used. Content analysis is to gather similar data within the frame of certain themes and contents and to interpret the data by organizing it so that readers can understand (Yıldırım \& Şimşek, 2011). Themes and subthemes were set and with the help of exact quotations of some participants' views were presented. For the privacy of the participants, since revealing their names is not appropriate, they were given a number while quoting from them. In order to ensure reliability, the researcher and a domain expert coded their views separately. The researcher and domain expert's coding was calculated based on Miles and Huberman's Concensus/Concensus+Dissensus formula (1994). The reliability of the study was calculated as 0.91 . Therefore, the study was accepted as reliable. 


\section{Results}

The findings obtained from the participants' views related to the questions asked in the study are presented in the tables below. While reporting findings, two headings were identified as the findings about the reasons for success and the findings about the reasons for failure.

\subsection{Findings about the Reasons for Success}

First, the findings about the reasons for success according to the participants who consider themselves as successful are introduced. Table 2 presents the findings about one of the research questions, personal factors, for success.

Table 2. Students' views about the reasons for success as personal factors

\begin{tabular}{|c|c|c|c|}
\hline & Subthemes & Students' views & f \\
\hline & & I study thinking that I will have a profession in the future & 1 \\
\hline & & I study because I have fear of failure & 1 \\
\hline & & I study to prove myself & 1 \\
\hline & & I study thinking that I will be rewarded for my effort & 1 \\
\hline & & I study because I want to serve as a model for people & 1 \\
\hline & & I study to improve the quality of my life & 1 \\
\hline & & I study because I want to contribute to my family & 1 \\
\hline & & I study because I want to serve my country & 1 \\
\hline & & I study because I have fear of disappointing my family & 1 \\
\hline & & I study because I want to be successful & 2 \\
\hline & & I study because I want to be a generalist & 1 \\
\hline$\ddot{0}$ & & I want to have knowledge in every field & 1 \\
\hline$\stackrel{\widetilde{\sigma}}{ \pm}$ & & I have desire to study & 1 \\
\hline 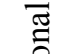 & Motivation & I give importance to my lessons & 1 \\
\hline dे & & I study in order to get over being homesick & 1 \\
\hline & & I want to be the best among my friends & 1 \\
\hline & & I always want the best of all & 1 \\
\hline & & I love my department & 1 \\
\hline & & I want to be a teacher who leaves students with an impression & 1 \\
\hline & & I want to know the information I obtain by heart & 2 \\
\hline & & I love researching & 1 \\
\hline & & I love to improve myself & 1 \\
\hline & & I love to enhance myself with new knowledge & 1 \\
\hline & & I want to be a role model for my siblings & 1 \\
\hline & & I think my family will be happy if I do well for myself & 1 \\
\hline & & I study more lest my scholarship will be discontinued & 1 \\
\hline & & Positive comments I received when I passed the university exam & 1 \\
\hline
\end{tabular}




\section{Macrothink}

Journal of Educational Issues

ISSN 2377-2263

2020, Vol. 6, No. 2

\begin{tabular}{|c|c|c|c|}
\hline & & I am tenacious & 6 \\
\hline & & I am ambitious & 2 \\
\hline & & I am determined & 1 \\
\hline & & I am jealous & 1 \\
\hline & & I am disciplined & 1 \\
\hline & & I make right decisions & 1 \\
\hline & & I am eager to learn & 2 \\
\hline & Personal Traits & I am calm & 2 \\
\hline & & I stay away from stress & 1 \\
\hline & & I have high concentration & 1 \\
\hline & & I do not compare myself with anybody & 1 \\
\hline & & I never act impulsively & 1 \\
\hline & & I trust myself & 1 \\
\hline & & I am responsible & 3 \\
\hline$\frac{0}{0}$ & & I am social & 1 \\
\hline$\stackrel{\widetilde{\pi}}{=}$ & & I study regularly & 1 \\
\hline$\tilde{\Xi}$ & & I have a balanced diet & 1 \\
\hline 2 & & I sleep on time & 1 \\
\hline & & I have my own studying style & 1 \\
\hline & & I know what and when to study & 1 \\
\hline & & I keep up with the innovations and developments in my field & 1 \\
\hline & & I study what I learn by understanding the logic behind & 1 \\
\hline & & I listen to the lesson carefully & 3 \\
\hline & Studying Strategies & I review the lessons regularly & 3 \\
\hline & & I study for the exams beforehand & 1 \\
\hline & & I love to study & 3 \\
\hline & & I study curiously & 1 \\
\hline & & I comment and evaluate while studying & 1 \\
\hline & & I study vocally & 1 \\
\hline & & I focus on every single sentence in the subject I study & 1 \\
\hline & & I visualize what I study & 1 \\
\hline & & I do my homework meticulously & 1 \\
\hline
\end{tabular}

When looking at Table 2, that the personal factors of the participants who consider themselves as successful can be grouped in three subthemes is observed. These are "motivation", "personal traits" and "studying strategies". When evaluated as a whole, participants put forward several reasons related to personal factors. Under the motivation subtheme, the statements "I study because I want to be successful" and "I want to know the information I obtain by heart" stand out. Under the personal traits subtheme, the emphasis on the statements "I am tenacious", "I am responsible", "I am ambitious", "I am eager to learn" 
and "I am calm" stands out most. When looking at the studying strategies subtheme, the statements "I listen to the lesson carefully", "I review the lessons regularly" and "I love to study" play a part. At this point, the views of some participants are as follows.

Participant 4: I think I am successful because I want to know the information I obtain by heart.

Participant 17: I think tenacity and desire are definitely two factors that trigger me.

Participant 5: I listen to the lesson carefully; I understand the content during the lesson. This has a great impact on my success.

The findings about the other question of the research, family factors, are presented in Table 3.

Table 3. Students' views about the reasons for success as family factors

\begin{tabular}{|c|c|c|c|}
\hline \multirow{12}{*}{ 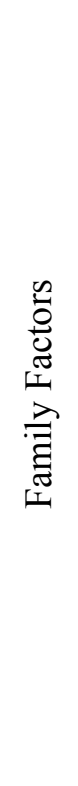 } & Subthemes & Students' views & f \\
\hline & \multirow{7}{*}{ Family Support } & My family is always there for me & 12 \\
\hline & & Especially my mother supports me & 2 \\
\hline & & Especially my father supports me & 2 \\
\hline & & My family trusts me & 3 \\
\hline & & My family cares my opinions & 2 \\
\hline & & I study in the city where my family lives & 2 \\
\hline & & My family always motivates me & 1 \\
\hline & Family Budget & My family has a low-income & 2 \\
\hline & \multirow{3}{*}{ Family Expectations } & I study in the city where my family lives & 2 \\
\hline & & My family wants me to study & 1 \\
\hline & & My family wants me to be in good conditions & 1 \\
\hline
\end{tabular}

When looking at Table 3, it is seen that the family factors of the participants who consider themselves as successful can be grouped in three subthemes. These are "family support", "family budget" and "family expectations". Under the family support subtheme, participants mostly stated "My family is always there for me" and "My family trusts me". As for the family budget subtheme, the statement "My family has a low-income" takes place. Under the family expectations subtheme, "I study in the city where my family lives" is the most stressed statement. At this point, the views of some participants are as follows.

Participant 14: My family is always there for me. My family always supports me to get on my feet financially with the help of a good education.

Participant 10: That my family has a low-income makes me feel that I have to be successful. My parents always tell me that I have to be successful. 
Table 4 presents the findings about the other question of the research, environmental factors.

Table 4. Students' views about the reasons for success as environmental factors

\begin{tabular}{|c|c|c|c|}
\hline \multirow{13}{*}{ 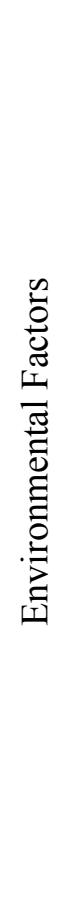 } & Subthemes & Students' views & $\mathbf{f}$ \\
\hline & \multirow{4}{*}{ Facilities } & Dormitory facilities are good & 6 \\
\hline & & University facilities are good & 5 \\
\hline & & I have a place to study alone & 1 \\
\hline & & $\begin{array}{l}\text { I can make plans and execute them as } \\
\text { I wish since I live in my own house }\end{array}$ & 1 \\
\hline & \multirow{3}{*}{ Social Circle } & I have a good social circle & 5 \\
\hline & & I have a limited social circle & 1 \\
\hline & & My friends support me & 2 \\
\hline & \multirow{5}{*}{ İnstructors } & My instructors support me & 1 \\
\hline & & My instructors are on students' side & 1 \\
\hline & & My instructors motivates the students & 1 \\
\hline & & My instructors are understanding & 1 \\
\hline & & My instructors have student-centered lessons & 1 \\
\hline
\end{tabular}

When looking at Table 4, that the environmental factors of the participants who consider themselves as successful can be grouped in three subthemes is observed. These are "facilities", "social circle" and "instructors". Under the facilities subtheme, participants mostly stated, "Dormitory facilities are good" and "University facilities are good". As for the social circle subtheme, the statement "I have a good social circle" takes place. Under the instructors subtheme, there is not a specific statement that was expressed frequently but there are statements like "My instructors have student-centered lessons" and "My instructors are on students' side". At this point, the views of some participants are as follows.

Participant 16: School and dormitory are two important places for success even though they are not like my family.

Participant 7: I suppose the biggest factor is my social circle because we chat and produce a good few new ideas about both assignments and daily issues.

Participant 10: My instructors carry out the lessons by getting the students involved.

\subsection{Findings about the Reasons for Failure}

Secondly, the findings about the reasons for failure according to the participants who consider themselves as unsuccessful are introduced. Table 5 presents the findings about personal factors for failure. 
Table 5. Students' views about the reasons for failure as personal factors

\begin{tabular}{|c|c|c|c|}
\hline & Subthemes & Students' views & f \\
\hline & & I do not like my department & 1 \\
\hline & & I do not like the school subjects & 2 \\
\hline & Personal Attitudes & I cannot get used to school & 1 \\
\hline & & I do not like the environment at university & 1 \\
\hline & & I cannot get used to the city I am in & 1 \\
\hline & & My social circle influences me & 3 \\
\hline & & I waste my time on my mobile & 1 \\
\hline & & I do not study regularly & 1 \\
\hline & & I graduated from distance education high school & 1 \\
\hline & & I study if my friends force me to do & 1 \\
\hline & 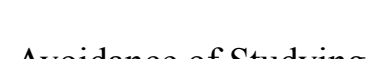 & I sleep too much & 1 \\
\hline & 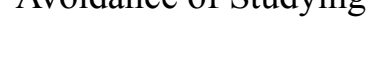 & I underestimate the exams & 1 \\
\hline & & I am too lazy & 1 \\
\hline 冚 & & It is not my wish to study & 1 \\
\hline 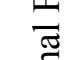 & & I overcome by languor & 1 \\
\hline D্ं & & I am indolent & 1 \\
\hline & & I cannot spare time to study & 1 \\
\hline & & I am obsessed & 1 \\
\hline & & I am not at peace with myself & 1 \\
\hline & & I do not have self-confidence & 3 \\
\hline & & I regard myself ineligible & 1 \\
\hline & & I lose my attention during the lesson & 1 \\
\hline & & I am too forgetful & 1 \\
\hline & Personal Traits & I have fear of being unsuccessful & 1 \\
\hline & & I have trouble in comprehension & 1 \\
\hline & & I get bored easily & 1 \\
\hline & & I do not enjoy life & 1 \\
\hline & & I feel anxious during the exams & 1 \\
\hline & & I have my personal problems & 1 \\
\hline & & I have trouble in communication & 1 \\
\hline
\end{tabular}

As can be seen in Table 5, three subthemes related to the personal factors according to the participants who consider themselves unsuccessful are introduced. These are "personal 
attitudes", "avoidance of studying" and "personal traits". When evaluated as a whole, participants put forward several reasons related to personal factors. Under the personal attitudes subtheme, the statement "I do not like school subjects" stands out whereas under the avoidance of studying subtheme, the emphasis on the statement "My social circle influences me" stands out most. When looking at the personal traits subtheme, it is seen that participants emphasized the statement "I do not have self-confidence" mostly. At this point, the views of some participants are as follows.

Participant 22: I do not like school subjects. Since the theory and practice are different from each other, I cannot run the risk of studying.

Participant 28: My friends do not study and they influence me.

Participant 23: I think I do not have self-confidence.

The findings about the other question of the research, family factors, are presented in Table 6 .

Table 6. Students' views about the reasons for failure as family factors

\begin{tabular}{|c|c|c|c|}
\hline & Subthemes & Students' views & $\mathbf{f}$ \\
\hline \multirow{9}{*}{ 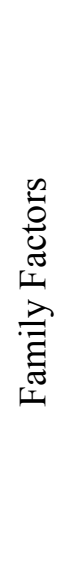 } & \multirow{9}{*}{ Family Situations } & My family does not believe in me & 1 \\
\hline & & My family does not think that I am intelligent enough & 1 \\
\hline & & Being away from my family decreases my motivation & 3 \\
\hline & & My family does not want me to study & 1 \\
\hline & & I am not allowed to study at home & 1 \\
\hline & & My family does not accept the department I want to study & 1 \\
\hline & & My family does not support me & 1 \\
\hline & & Financial difficulties restrain me from focusing on success & 1 \\
\hline & & My family does not guide me & 1 \\
\hline
\end{tabular}

When looking at Table 6, that the family factors of the participants who consider themselves as unsuccessful can be grouped in one subtheme, family situations. Under this subtheme, the statement "Being away from my family decreases my motivation" is the most emphasized one. At this point, the views of some participants are as follows.

Participant 30: Being away from my family decreases my motivation. Therefore, I cannot achieve the success that I want.

Participant 33: My family does not support or guide me.

Participant 24: My family never wants me to go to school and study.

The findings about the environmental factors are presented in Table 7. 
Table 7 Students' views about the reasons for failure as environmental factors

\begin{tabular}{|c|c|c|c|}
\hline & Subthemes & Students' views & f \\
\hline \multirow{14}{*}{ 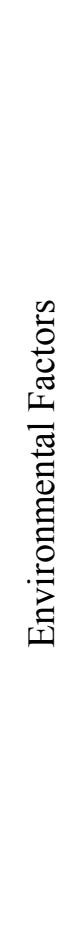 } & \multirow{7}{*}{ Instructors } & Instructors from other departments give lessons & 1 \\
\hline & & Instructors do not lead us in a correct way & 1 \\
\hline & & Instructors do not have communication with students & 1 \\
\hline & & Instructors are not fair & 4 \\
\hline & & Instructors do not value students & 1 \\
\hline & & Instructors do not provide high quality education & 1 \\
\hline & & Instructors provide rote learning & 1 \\
\hline & \multirow{2}{*}{ Social Circle } & There is a communication problem among the students in the class & 1 \\
\hline & & I cannot get along well with my roommates & 1 \\
\hline & \multirow{5}{*}{ Facilities } & There is block scheduling & 1 \\
\hline & & There is relative evaluation system & 2 \\
\hline & & There are not places like theatre hall & 1 \\
\hline & & I do not have internet access & 1 \\
\hline & & I do not have a place to study at the dormitory & 4 \\
\hline
\end{tabular}

As can be seen in Table 7, three subthemes related to the environmental factors according to the participants who consider themselves unsuccessful are introduced. These are "Instructors", "social circle" and "facilities". Under the instructors subtheme, the statement "Instructors are not fair" stands out whereas under the social circle subtheme, there is not a specific statement, which was frequently expressed, but there are statements like "There is a communication problem among the students in the class" and "I cannot get along well with my roommates". When looking at the facilities subtheme, participants emphasized the statements "I do not have a place to study at the dormitory" and "There is relative evaluation system" mostly. At this point, the views of some participants are as follows.

Participant 25: I have a low GPA because of the curve system. I got low scores from the lessons that have high credits. The main reason is that some instructors favor some students.

Participant 24: Everybody in the class has a different group of friends and they do not have a proper communication.

Participant 26: It is hard to study at a small desk at the dormitory. I cannot study in limited areas.

\section{Discussion}

In this research, university students' perceptions of success, failure, and the reasons for them were examined. At this point, it was aimed to reveal the reasons for success and failure in a general sense. The research is limited to 34 university students and the only data collection 
tool was interview. Remarkable results emerged in this study where students' views about success and failure were examined. The reasons for success and failure were grouped under three themes as personal, family and environmental factors. According to the results of the research, the factor that affects both success and failure most is personal. Similarly, Sezer (2016) also states that individuals consider the reasons for failure as themselves. Three subthemes, motivation, personal traits and studying strategies, were identified related to the personal factors for success. The fact that the students want to be successful, to know the information they obtain by heart, to prove themselves, to model for others and love to research is the key element of motivation. Personal traits such as being tenacious, ambitious, responsible, eager to learn and calm are also the reasons for success. Studying strategies such as listening to the lesson carefully, reviewing the lesson regularly and loving to study is considered as the reasons for success. When it comes to the personal factors for failure, three subthemes, personal attitudes, avoidance of studying and personal traits, were identified. Being influenced by the social circle, lack of self-confidence, forgetfulness, distractibility and dislike of the lessons are the key elements of failure.

In parallel with the findings of the study, Kurt and Erdem (2012) suggested that individuals' future expectations, personal traits and whether they adopt their departments or not affect success. Moreover, Gavcar, Ülkü, and Ekmekci (2001), Özer and Sarı (2009) emphasized that the students who adopt their departments become more successful. Aysan, Tanriöğen, and Tanriöğen (1996) also mentioned that lack of regular study, psychological problems and lack of the ability of time use are the personal factors for failure. While Dursun and Dede (2004) expressed that listening to the lesson carefully affects success, Rençber (2012) stated that class attendance affects success. Sayin and Gelbal (2014) reported that listening to the lesson carefully and studying in a disciplined way play an important role in success. This situation shows that student's personal traits, studying strategies, attitudes and motivation are important factors for success and failure.

Three subthemes, family support, family budget and family expectation, were identified related to the family factors for success. It was observed that family support; for example, the family is always there for the student, they always trust and motivate the student, is one of the major elements for success as well as the family's low-income and the family expects the student to be successful. In addition, being away from the family, lack of family support and belief are among the reasons for failure. There are studies which prove that low-income is the reason for failure (Seven \& Engin, 2008; Gavcar, Ülkü, \& Ekmekçi, 2001). In this research, family's budget is the reason for both success and failure. Although it seems like a contradiction, financial difficulties motivate some students whereas they make others lose their motivation. Hence, when looking at the previous meta-analysis studies, Liu, Peng, and Luo (2020) detected a relation between economic condition and success at an intermediate level while White (1982) claimed that there is a relation at a low level. Şirin (2005), who claims that he conducted the same research as White's, suggested that there is a slight decrease in correlation. Besides, whether the student stays with the family or is away from the family is an important reason for success and failure. Some participants lay weight on the support of their mothers or their fathers as the reason for their success. This makes one think 
that the attitude of the parents might be related to their education levels. There are quite a few studies proving that educated parents influence individual's success positively (An1l, 2010; Ural \& Çınar, 2014; Bölükbaş, 2010).

Three subthemes, facilities, social circle and instructors, were identified related to the environmental factors for success. Dormitory and university facilities, having a good social circle and support of instructors are among the reasons for success. As for the environmental factors for failure, the same three subthemes were identified; that is, facilities, social circle and instructors. The fact that instructors are not fair, there are communication problems in the class, there is not an appropriate place to study at the dormitory and there is relative evaluation system is regarded as the reason for failure. Since some students consider the dormitory where they stay as the reason for success while others as the reason for failure, it is thought that dormitory facilities can tell the difference. In other words, success depends on the facilities of the dormitory. Furthermore, the instructors who do not act fairly are considered as significant reasons for failure. Polat and Taştan (2009) detected a relation between trust and success at a high level. They stated that trust is an important explanation of success. Similarly, Özer, Dönmez, and Atik (2016) suggested that there is a relation between success and students' trust towards instructors. In the same study, that social circle and accommodation are important elements for success and failure was observed. According to Şeker, Çınar, and Özkaya (2004), social circle has an effect on success; however, the place where students live during the university years has no effect on it. Seven and Engin (2008) emphasized that school's inappropriate physical conditions bring failure. Sayın and Gelbal (2014) stressed that instructors' level of competence, methods and strategies play a role in achieving success. These findings coincide with the ones presented above.

When evaluated as a whole, this study illustrates that family, environmental and personal factors in particular have profound effects on student's success. The students who took part in the research are assumed to be placed in their departments with a high score. In other words, those students were already successful when they first started university. Despite this, that some of them consider themselves as unsuccessful in forthcoming education years indicates that there may be other factors affecting their success after they start university. Therefore, students need monitoring and providing with both learning and accommodation facilities organized in accordance with their needs and interests after they are placed in university. One must remember that several students leave their families and try to study in different cities and one must not ignore that this separation may cause failure. As for the instructors, they must follow accountability criteria so that students can feel justice.

The most remarkable point in the research is that there are students who consider themselves as unsuccessful even though they do have a high GPA and there are students who consider themselves as successful even though they do not have a high GPA. This situation shows that success is a relative concept. Successful students who feel unsuccessful must be monitored carefully and supported since they might have the purpose of being better. The success expectations of the students who consider themselves as successful but have low scores can be questioned. Misperceptions of these students can be corrected by conducting different scientific research in smaller groups with different methods. 
By looking at the results of the study, some implications are presented below:

- Further studies may be conducted in order to reveal students' success and failure in different sampling groups.

- Further studies may be conducted in order to monitor how university students' success changes throughout their university lives.

- Further studies may be conducted in order to provide different perspectives by investigating the reasons for success and failure based on the views of families and academics.

\section{References}

Akbaba-Altun, S. (2009). İlköğretim öğrencilerinin akademik başarısızlıklarına ilişkin veli, öğretmen ve öğrenci görüşlerinin incelenmesi. Elementary Education Online, 8(2), 567-586.

Akbaba-Altun, S., \& Çakan, M. (2008). Öğrencilerin sınav başarılarına etki eden faktörler: LGS/ÖSS sınavlarındaki başarılı iller örneği. Elementary Education Online, 7(1), 157-173.

Altınkurt, Y. (2008). Öğrenci devamsızlıklarının nedenleri ve devamsızlığın akademik başarıya olan etkisi. Dumlupınar Üniversitesi Sosyal Bilimler Dergisi, 20, 129-142.

Anıl, D. (2010). Uluslararası öğrenci başarılarını değerlendirme programı (PISA)'nda Türkiye'deki öğrencilerin fen bilimleri başarılarını etkileyen faktörler. Ĕğtim ve Bilim, 34(152), 87-100.

Arıcı, İ. (2007a). Öğrencilerin ilköğretim din kültürü ve ahlak bilgisi dersi öğretmenine yönelik tutumları. Ilahiyat Fakültesi Dergisi, 12(2), 169-189.

Arıcı, İ. (2007b). Öğrenci ailelerinin sosyo-ekonomik düzeylerinin ilköğretim din kültürü ve ahlak bilgisi dersindeki başarılarına etkisi. Illahiyat Fakültesi Dergisi, 12(2), 151-168.

Aslanargun, E. (2007). Okul-Aile iş birliği ve öğrenci başarısı üzerine bir tarama çalışma. Sosyal Bilimler Dergisi, 18, 119-135.

Aysan, F., Tanrı̈̆ğen, G., \& Tanrı̈̈̆gen, A. (1996). Perceived Causes of Academic Failure Among the Students at the Faculty of Education at Buca. In Y. Kitap \& G. Karagözoğlu (Eds.), Teacher Training for the Twenty First Century. İzmir: Buca Eğitim Fakültesi Yay.

Baş, T., \& Akturan, U. (2013). Nitel araştırma yöntemleri: NVivo ile nitel veri analizi. Ankara: Seçkin Yayıncılık.

Bean, R. A., Bush, K. R., McKenry, P. C., \& Wilson, S. M. (2003). The Impact of parental, support, behavioral control, and psychological control on the academic achievement and self-esteem of African-American and European American Adolescents. Journal of Adolescent Research, 18(5), 523-541. https://doi.org/10.1177/0743558403255070

Bölükbaş, F. (2010). İlköğretim Öğrencilerinin Türkçe Dersine Yönelik Tutumlarının Başarı, Cinsiyet, Ailenin Eğitim Düzeyi Bağlamında Değerlendirilmesi. Turkish Studies, 5(3), 
905-918.

Boozer, M., \& Rouse, C. (2001). Intraschool variation in Class Size: Patterns and implications. Journal of Urban Economics, 50(1), 163-189. https://doi.org/10.1006/juec. 2001.2216

Büyüköztürk, Ş., Kılıç-Çakmak, E., Akgün, Ö. E., Karadeniz, Ş., \& Demirel, F. (2012). Bilimsel araştırma yöntemleri (11th ed.). Ankara: Pegem Akademi.

Çalık, T. (2011). Sınıf yönetimi ile ilgili temel kavramlar. In L. Küçükahmet (Ed.), Sınıf Yönetimi. Ankara: Pegem Akademi Yayıncılık.

Creswell, J. W. (2007). Qualitative inquiry and research design: Choosing among five approaches. London: SAGE Publication.

Dursun, Ş., \& Dede, Y. (2004). Öğrencilerin matematikte başarısını etkileyen faktörler matematik öğretmenlerinin görüşleri bakımından. Gazi Üniversitesi Gazi Eğitim Fakültesi Dergisi, 24(2), 217-230.

Erdil, Z. (2010). Sosyoekonomik olarak risk altında bulunan çocuklara yönelik erken müdahale programları ve akademik başarı ilişkisi. Sağlık Bilimleri Fakültesi Hemşirelik Dergisi, 17(1), 72-78.

Gavcar, E., Ülkü, M., \& Ekmekçi, S. (2001). Üniversite Öğrencilerinin Başarıları Üzerine Etki Eden Bazı Faktörlerin Araştırılması (Muğla Üniversitesi İİ BF Örneği). Sosyal ve Beşerî Bilimler Araştırmaları Dergisi, 1(5).

Kandemir, M. (2012). Öğrencilerinin akademik erteleme davranışlarının, kaygı, başarısızlık korkusu, benlik saygısı ve başarı amaçları ile açıklanması. Pegem Ĕ̆itim ve Öğretim Dergisi, 2(4), 81-88. https://doi.org/10.14527/C2S4M7

Klomegah, R. Y. (2007). Predictors of academic performance of university students: an application of the goal efficacy model. College Student Journal, 41(2), 407-415.

Kurt, Ç., \& Erdem, O. A. (2012). Öğrenci başarısını etkileyen faktörlerin veri madenciliği yöntemleriyle incelenmesi. Politeknik Dergisi, 15(2), 111-116.

Liu, J., Peng, P., \& Luo, L. (2020). The relation between family socioeconomic status and academic achievement in China: a meta-analysis. Educational Psychology Review, 32(1), 49-76. https://doi.org/10.1007/s10648-019-09494-0

Maton, K. I., Hrabowski, F. A., \& Greif, G. L. (1998). Preparing the way: A qualitative study of high-achieving African American Males and the role of the family. American Journal of Community Psychology, 26(4), 639-668. https://doi.org/10.1023/A:1022197006900

Mayring, P. (2000). Nitel sosyal araştırmaya giriş. In A. Gümüş \& M. S. Durgun (Eds.), Adana: Baki.

Miles, M. B., \& Huberman, A. M. (1994). Qualitative data analysis: an expanded sourcebook (2nd ed.). USA: SAGE. 
Özabac1, N., \& Acat, M. B. (2005). Sosyo ekonomik çevreye göre ilköğretim öğrencilerinin başarısızlık nedenleri. Eskişehir Osmangazi Üniversitesi Eğitim Fakültesi Dergisi, 6(1), 145-170.

Özer, H., \& Sarı, A. (2009). Kovaryans analizi modelleriyle üniversite öğrencilerinin başarılarını etkileyen faktörlerin belirlenmesi: atatürk üniversitesi iibf öğrencileri için bir uygulama. Dokuz Eylül Üniversitesi İktisadi ve İdari Bilimler Fakültesi Dergisi, 24(2), 105-126.

Özer, N., Dönmez, B., \& Atik, S. (2016). Ortaokul ve lise öğrencilerinin okul müdürüne ve öğretmenlere güven düzeyinin incelenmesi. CÜ Sosyal Bilimler Dergisi, 40(1), 259-280.

Özer, Y., \& Anıl, D. (2011). Öğrencilerin fen ve matematik başarılarını etkileyen faktörlerin yapısal eşitlik modeli ile incelenmesi. Hacettepe Üniversitesi Eğitim Fakültesi Dergisi, 41, 313-324.

Patır, S., \& Yıldız, M. S. (2008). İktisadi ve idari bilimler fakültesi işletme bölümü öğrencilerinin sayısal derslerdeki başarısızlık nedenleri ve çözüm önerileri. Suleyman Demirel University Journal of Faculty of Economics \& Administrative Sciences, 13(1), 293-316.

Polat, S. (2009). Akademik başarısızlığın toplumsal eşitsizlik temelinde çözümlenmesi. Eğitim Bilim Toplum Dergisi, 7(25), 46-61.

Polat, S., \& Taştan, M. (2009). Yükseköğretim öğrencilerinin öğretim elemanlarına güven düzeyi ile akademik başarıları arasındaki ilişki. New World Sciences Academy (e-Journal of New World Sciences Academy), 4(2), 558-574.

Purdue, N., \& Hattie, J. (1999). The relationship between study skills and learning outcomes: A meta-analysis. Australian Journal of Education, 43(1), 72-86. https://doi.org/10.1177/ 000494419904300106

Rençber, B. A. (2012). Üniversite öğrencilerinin akademik başarılarını etkileyen faktörler. Çankırı Karatekin Üniversitesi Sosyal Bilimler Enstitüsü Dergisi, 3(1), 191-198.

Şama, E., \& Tarım, K. (2007). Öğretmenlerin başarısız olarak algıladıkları öğrencilere yönelik tutum ve davranışları. Türk Eğitim Bilimleri Dergisi, 5(1), 135-154.

Sayın, A., \& Gelbal, S. (2014). Başarıyı etkileyen faktörlerin önem derecelerinin ardışık aralıklar yöntemiyle ölçeklenmesi. Amasya Üniversitesi Eğitim Fakültesi Dergisi, 3(1), 1-26.

Şeker, R., Çınar, D., \& Özkaya, A. (2004). Çevresel faktörlerin üniversite öğrencilerinin başarı düzeyine etkileri (pp. 6-9). XIII. Ulusal Eğitim Bilimleri Kurultayı.

Seven, M. A., \& Engin, A. O. (2008). Öğrenmeyi etkileyen faktörler. Atatürk Üniversitesi Sosyal Bilimler Enstitüsü Dergisi, 12(2), 189-212.

Sezer, F. (2016). Causes of failure from students' point of view Öğrenci gözüyle başarısızlığının nedenleri. Journal of Human Sciences, 13(3), 4818-4830. https://doi.org/ 10.14687/jhs.v13i3.4157 


\section{Macrothink}

Silah, M. (1994). Üniversite öğrencilerinin akademik başarılarını etkileyen çeşitli nedenler arasında süreksiz durumluk kaygının yeri ve önemi. Eğitim Araştırmalar Dergisi, 10, $102-115$.

Şirin, S. R. (2005). Socioeconomic status and academic achievement: A meta-analytic review of research. Review of Educational Research, 75(3), 417-453. https://doi.org/10.3102/00346 543075003417

Soydaş, E., \& Bayraker, E. (2006). Başarısızlık Nedenleri Anketi Sonuç Değerlendirme. Sorgun: Rehberlik ve Araştırma Merkezi. Retrieved from http://bulancakanadolu.meb.k12.tr/ meb_iys_dosyalar/28/03/874951/dosyalar/2017_12/26133214_baYarYsYzlYk_nedenleri_de Yerlendirme.pdf

Taylor, S. J., \& Bogdan, R. (1984). Introduction to qualitative research methods: The search for meaning (2nd ed.). USA: John Wiley \& Sons.

Tezcan, M. (1999). Eğitim Sosyolojisi (12th ed.). Ankara: Şafak Matbaacılık.

Topbaş, S. (1998). Öğrenme güçlüğü gözlenenler. In S. Eripek(Ed.), Özel Eğitim. Eskişehir: Anadolu Üniversitesi Yayınları.

Ural, A., \& Çınar, F. N. (2014). Anne ve babanın eğitim düzeyinin öğrencinin matematik başarısına etkisi. Mehmet Akif Ersoy Üniversitesi Eğitim Bilimleri Enstitüsü Dergisi, 3(4), 42-57.

Wang, D. B. (2004). Family background factors and mathematics success: A comparison of Chinese and US students. International Journal of Educational Research, 41, 40-54. https://doi.org/10.1016/j.ijer.2005.04.013

White, K. (1982). The relation between socioeconomic status and academic achievement. Psychological Bulletin, 91, 461-481. https://doi.org/10.1037/0033-2909.91.3.461

Yaşar, M., \& Balkıs, M. (2004). Pamukkale Üniversitesi Eğitim Fakültesinde yaz okuluna kayıt yaptıran öğrencilerin başarısızlık nedenlerinin incelenmesi. Pamukkale Üniversitesi Ĕ̈itim Fakültesi Dergisi, 15(1), 130-165.

Yıldırım, A., \& Şimşek, H. (2011). Sosyal bilimlerde nitel araştırma yöntemleri (8th ed.). Ankara: Seçkin.

\section{Copyright Disclaimer}

Copyright for this article is retained by the author(s), with first publication rights granted to the journal.

This is an open-access article distributed under the terms and conditions of the Creative Commons Attribution license (http://creativecommons.org/licenses/by/3.0/). 